\title{
The effect of MG132, a proteasome inhibitor on HeLa cells in relation to cell growth, reactive oxygen species and GSH
}

\author{
YONG HWAN HAN, HWA JIN MOON, BO RA YOU and WOO HYUN PARK \\ Department of Physiology, Medical School, Centers for Healthcare Technology Development \\ Institute for Medical Sciences Chonbuk National University, JeonJu 561-180, Korea
}

Received March 16, 2009; Accepted April 29, 2009

DOI: $10.3892 /$ or_00000427

\begin{abstract}
MG132 (carbobenzoxy-Leu-Leu-leucinal) is a peptide aldehyde, which effectively blocks the proteolytic activity of the $26 \mathrm{~S}$ proteasome complex. We evaluated the effects of MG132 on the growth of human cervix cancer HeLa cells in relation to the cell growth, reactive oxygen species (ROS) and glutathione (GSH) levels. Dose-dependent inhibition of cell growth was observed in HeLa cells with an $\mathrm{IC}_{50}$ of approximately $5 \mu \mathrm{M}$ MG132 for $24 \mathrm{~h}$. DNA flow cytometric analysis indicated that treatment with MG132 induced S, G2-M or non-specific phase arrests of the cell cycle dose-dependently. Treatment with MG132 induced apoptosis in a dose-dependent manner, as evidenced by subG1 cells and annexin V staining cells. Treatment with MG132 also induced the loss of mitochondrial membrane potential in HeLa cells. The intracellular ROS levels including $\mathrm{O}_{2}{ }^{-}$were significantly increased in MG132-treated cells. Furthermore, the depletion of intracellular GSH content was observed in cells treated with MG132. In conclusion, MG132 inhibited the growth of HeLa cells via inducing the cell cycle arrest as well as triggering apoptosis. The changes of ROS and GSH by MG132 were closely related to apoptosis in HeLa cells.
\end{abstract}

\section{Introduction}

Reactive oxygen species (ROS) include hydrogen peroxide $\left(\mathrm{H}_{2} \mathrm{O}_{2}\right)$, superoxide anion $\mathrm{O}_{2}{ }^{-*}$ and hydroxyl radical ${ }^{\circ} \mathrm{OH}$.

Correspondence to: Dr Woo Hyun Park, Department of Physiology, Medical School, Chonbuk National University, JeonJu, Korea

E-mail: parkwh71@chonbuk.ac.kr

Abbreviations: MG132, carbobenzoxy-Leu-Leu-leucinal; ROS, reactive oxygen species; MMP, mitochondrial membrane potential $\left(\Delta \Psi_{\mathrm{m}}\right)$; CDK, cyclin-dependent kinase; FBS, fetal bovine serum; MTT, 3-(4,5-dimethylthiazol-2-yl)-2,5-diphenyltetrazolium bromide; PI, propidium iodide; FITC, fluorescein isothiocyanate; $\mathrm{H}_{2}$ DCFDA, 2',7'-Dichlorodihydrofluorescein diacetate; DHE, dihydroethidium; GSH, glutathione; CMFDA, 5-chloromethylfluorescein diacetate

Key words: MG132, cell cycle, apoptosis, HeLa, reactive oxygen species, glutathione
These molecules have recently been implicated in regulating many important cellular events, including transcription factor activation, gene expression, differentiation and cell proliferation $(1,2)$. ROS are formed as by-products of mitochondrial respiration or the action of oxidases, including nicotine adenine diphosphate (NADPH) oxidase, xanthine oxidase (XO) and certain arachidonic acid oxygenases (3). A change in the redox state of a tissue implies a change in ROS generation or metabolism. The principal metabolic pathways include superoxide dismutase (SOD), which is expressed as extracellular, intracellular and mitochondrial isoforms. These isoforms metabolize $\mathrm{O}_{2}{ }^{-}$to $\mathrm{H}_{2} \mathrm{O}_{2}$. Further metabolism by peroxidases, which include catalase and glutathione (GSH) peroxidase, yields $\mathrm{O}_{2}$ and $\mathrm{H}_{2} \mathrm{O}$ (4). GSH is the main nonprotein antioxidant in the cell and provides electrons for enzymes such as glutathione peroxidase, which reduce $\mathrm{H}_{2} \mathrm{O}_{2}$ to $\mathrm{H}_{2} \mathrm{O}$. GSH has been shown to be crucial for cell proliferation, cell cycle progression and apoptosis $(5,6)$ and is known to protect cells from toxic insult by detoxifying toxic metabolites of drugs and ROS (7). Although cells possess antioxidant systems to control their redox state, which is important for their survival, excessive production of ROS can be induced and gives rise to the activation of events that lead to death or survival in different cell types (8-10).

The ubiquitin-proteasomal system represents the major non-lysosomal pathway through which intracellular proteins involved in cell cycling, proliferation, differentiation and apoptosis are degraded in eukaryotic cells $(11,12)$. The proteasomes are large multi-subunit protease complexes, which are present in both the cytoplasm and nucleus of all eukaryotic cells. The $26 \mathrm{~S}$ proteasome is composed of 2 functional components: a 20S catalytic and two 19S regulatory subunits. The protease activity resides in a channel at the center of the $20 \mathrm{~S}$ subunit, and exhibits 3 distinguishable enzymatic activities: chymotrypsin-like, trypsin-like and caspase-like (13). Many proteins degraded by proteasome are implicated in crucial processes: for example, cell cycle-regulatory proteins (cyclins A, B, D and E; p21 and p27) and apoptoticrelated proteins (p53 and Bcl-2) (14). Transformed cells including cancer cells accumulate more misfoled/mutated/ damaged proteins due to the high replication rate of malignant cells, which are disposed of by the proteasome (14). Thus, these cells are much more susceptible to proteasome inhibition than normal cells. Apoptosis in cancer cells is closely connected with the activity of ubiquitin/ 
proteasome pathways $(15,16)$. Accordingly, the proteasome has emerged as an attractive target for cancer therapy. MG132 (carbobenzoxy-Leu-Leu-leucinal) is a peptide aldehyde, which effectively blocks the proteolytic activity of the $26 \mathrm{~S}$ proteasome complex, being a potent inhibitor of the chymotryptic-like activity (17). Proteasome inhibitors including MG132 have been shown to induce apoptotic cell death through formation of ROS (18-22). ROS formation and GSH depletion due to proteasome inhibitors may cause mitochondrial dysfunction and subsequent cytochrome $\mathrm{c}$ release, which leads to cell viability loss $(20,23)$. The mechanism underlying ROS generation after inhibition of proteasome is still unclear.

In the present study, we investigated the effects of the proteasome inhibitor MG132 on the growth of human cervix cancer HeLa cells in relation to the cell cycle and apoptosis. Furthermore, we evaluated the changes of ROS and GSH levels in MG132-treated HeLa cells.

\section{Materials and methods}

Cell culture. The human cervix adenocarcinoma HeLa cells were obtained from the ATCC and maintained in a humidified incubator containing $5 \% \mathrm{CO}_{2}$ at $37^{\circ} \mathrm{C}$. HeLa cells were cultured in RPMI-1640 supplemented with $10 \%$ fetal bovine serum (FBS) and 1\% penicillin-streptomycin (Gibco BRL, Grand Island, NY). Cells were routinely grown in 100-mm plastic tissue culture dishes (Nunc, Roskilde, Denmark) and harvested with a solution of trypsin-EDTA while in a logarithmic phase of growth. Cells were maintained in these culture conditions for all experiments.

Reagents. MG132 was purchased from Calbiochem (San Diego, CA). MG132 was dissolved in DMSO solution buffer at $10 \mathrm{mM}$ as a stock solution. DMSO was used as a control vehicle. MG132 stock solution was wrapped in foil and kept at $-20^{\circ} \mathrm{C}$.

Cell growth assay. The effect of MG132 on HeLa cell growth was determined by trypan blue exclusion cell counting or measuring 3-(4,5-dimethylthiazol-2-yl)-2,5diphenyltetrazolium bromide (MTT) dye absorbance of living cells as previously described (24). In brief, cells $\left(5 \times 10^{5}\right.$ cells per well) were seeded in 24-well plates (Nunc, Roskilde, Denmark) for cell counting, and cells $\left(5 \times 10^{4}\right.$ cells per well) were seeded in 96-well microtiter plates for the MTT assay. After exposure to indicated amounts of MG132 for $24 \mathrm{~h}$, cells in 24-well plates or 96-well plates were collected with trypsin digestion for trypan blue exclusion cell counting or were used for the MTT assay. Twenty microliters of MTT (Sigma) solution $(2 \mathrm{mg} / \mathrm{ml}$ in PBS) was added to each well of 96 -well plates. The plates were again incubated for $4 \mathrm{~h}$ at $37^{\circ} \mathrm{C}$. MTT solution in the medium was aspirated off and $200 \mu 1$ of DMSO was added to each well to solubilize the formazan crystals formed in viable cells. Optical density was measured at $570 \mathrm{~nm}$ using a microplate reader (Spectra MAX 340, Molecular Devices Co, Sunnyvale, CA). Each plate contained multiple wells at a given experimental condition and multiple control wells. This procedure was replicated for 2-4 plates per condition.
Cell cycle and sub-Gl analysis. The cell cycle distributions and sub-G1 cells were determined by staining of DNA with propidium iodide (PI; Sigma-Aldrich) $(\mathrm{Ex} / \mathrm{Em}=488 \mathrm{~nm} /$ $617 \mathrm{~nm}$ ) as previously described (25). PI is a fluorescent biomolecule that can be used to stain DNA. In brief, $1 \times 10^{6}$ cells were incubated with the designated doses of MG132 for $24 \mathrm{~h}$. Cells were then washed with phosphate-buffered saline (PBS) and fixed in $70 \%$ ethanol. Cells were washed again with PBS and then incubated with PI $(10 \mu \mathrm{g} / \mathrm{ml})$ with simultaneous treatment of RNase at $37^{\circ} \mathrm{C}$ for $30 \mathrm{~min}$. The percentages of cells in different phases of the cell cycle or having sub-G1 DNA content were measured with a FACStar flow cytometer (Becton-Dickinson, San Jose, CA) and analyzed using lysis II and CellFIT software (Becton-Dickinson) or ModFit software (Verity Software House, Inc. ME).

Annexin $V$ staining. Apoptosis was determined by staining cells with annexin V-fluorescein isothiocyanate (FITC) $(\mathrm{Ex} / \mathrm{Em}=488 \mathrm{~nm} / 519 \mathrm{~nm})$, because annexin $\mathrm{V}$ can be used to identify the externalization of phosphatidylserine during the progression of apoptosis and, therefore, can detect cells during early phases of apoptosis. In brief, $1 \times 10^{6}$ cells were incubated with the designated doses of MG132 for $24 \mathrm{~h}$. Cells were washed twice with cold PBS and then resuspended in $500 \mu \mathrm{l}$ of binding buffer $(10 \mathrm{mM}$ HEPES/NaOH pH 7.4, $140 \mathrm{mM} \mathrm{NaCl}, 2.5 \mathrm{mM} \mathrm{CaCl}_{2}$ ) at a concentration of $1 \times 10^{6}$ cells $/ \mathrm{ml}$. Five microliters of annexin V-FITC (PharMingen, San Diego, CA) was then added to these cells, which were analyzed with a FACStar flow cytometer (BectonDickinson).

Measurement of mitochondrial membrane potential (MMP) $\left(\Delta \Psi_{m}\right)$. The MMP was measured using the Rhodamine 123 fluorescent dye $(E x / E m=485 \mathrm{~nm} / 535 \mathrm{~nm})$, a cell-permeable cationic dye, which preferentially enters mitochondria based on the highly negative MMP $\left(\Delta \Psi_{\mathrm{m}}\right)$. Depolarization of MMP $\left(\Delta \Psi_{\mathrm{m}}\right)$ results in the loss of Rhodamine 123 from the mitochondria and a decrease in intracellular fluorescence of Rhodamine 123 . In brief, $1 \times 10^{6}$ cells were incubated with the designated doses of MG132 for $24 \mathrm{~h}$. Cells were washed twice with PBS and incubated with Rhodamine $123(0.1 \mu \mathrm{g} / \mathrm{ml}$; Sigma) at $37^{\circ} \mathrm{C}$ for $30 \mathrm{~min}$. Rhodamine 123 staining intensity was determined by flow cytometry of a FACStar flow cytometer (Becton-Dickinson). Rhodamine 123 negative cells indicate the loss of MMP $\left(\Delta \Psi_{\mathrm{m}}\right)$ in HeLa cells. MMP $\left(\Delta \Psi_{\mathrm{m}}\right)$ levels in cells except the MMP $\left(\Delta \Psi_{\mathrm{m}}\right)$ loss cells were expressed as mean fluorescence intensity (MFI), which was calculated by CellQuest software.

Detection of intracellular $\mathrm{ROS}$ and $\mathrm{O}_{2}^{--}$levels. Intracellular ROS such as $\mathrm{H}_{2} \mathrm{O}_{2},{ }^{\circ} \mathrm{OH}$ and $\mathrm{ONOO}^{\bullet}$ were detected by means of an oxidation-sensitive fluorescent probe dye, 2',7'-dichlorodihydrofluorescein diacetate $\left(\mathrm{H}_{2} \mathrm{DCFDA}\right)(26,27)$ (Invitrogen Molecular Probes, Eugene, OR). $\mathrm{H}_{2}$ DCFDA was deacetylated intracellularly by non-specific esterase, which was further oxidized by cellular peroxides, yielding 2,7-dichlorofluorescein (DCF), a fluorescent compound $(\mathrm{Ex} / \mathrm{Em}=495 \mathrm{~nm} / 529 \mathrm{~nm})$. DCF is poorly selective for superoxide anion radical $\left(\mathrm{O}_{2}{ }^{-}\right)$. In contrast, dihydroethidium $(\mathrm{DHE})(\mathrm{Ex} / \mathrm{Em}=518 \mathrm{~nm} / 605 \mathrm{~nm})$ 
A

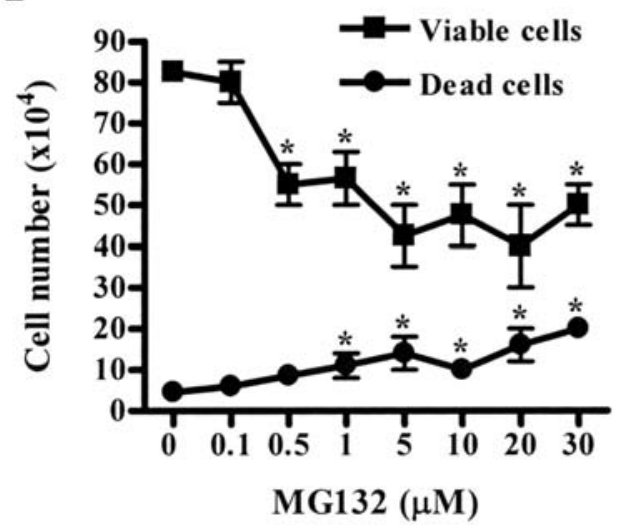

B

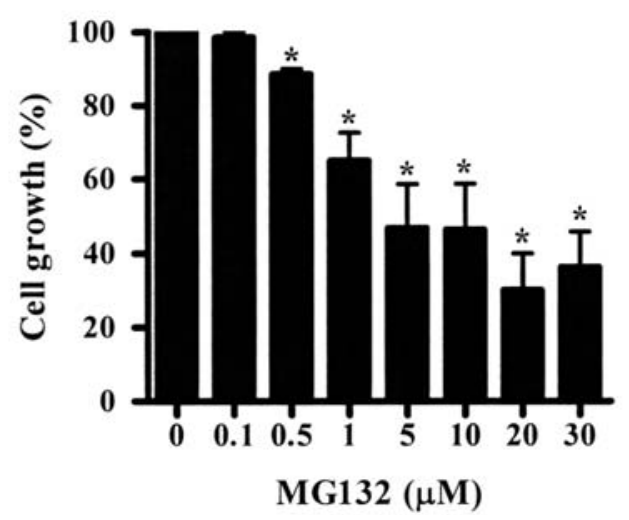

Figure 1. Effects of MG132 on the growth of HeLa cells in vitro. Exponentially-growing cells were treated with the indicated concentrations of MG132 for 24 h. Cell number (A) and cell growth (B) were assessed by trypan blue exclusion cell counting and the MTT assay, respectively. ${ }^{*} \mathrm{P}<0.05$ compared with the MG132-untreated control cell group. Data are presented as means \pm SD of 3 replicates.

(Invitrogen Molecular Probes) is a fluorogenic probe that is highly selective for $\mathrm{O}_{2}{ }^{-*}$ among ROS. DHE is cell-permeable and reacts with superoxide anion to form ethidium, which in turn intercalates in deoxyribonucleic acid, thereby exhibiting a red fluorescence. Mitochondrial $\mathrm{O}_{2}{ }^{--}$levels were detected using MitoSOX ${ }^{\mathrm{TM}}$ Red mitochondrial $\mathrm{O}_{2}{ }^{*-}$ indicator (Invitrogen Molecular Probes) as previously described (27). MitoSOX $^{\mathrm{TM}}$ Red is a fluorogenic dye for highly selective detection of $\mathrm{O}_{2}{ }^{--}$in the mitochondria of live cells. Once in the mitochondria, MitoSOX ${ }^{\mathrm{TM}}$ Red agent is oxidized by $\mathrm{O}_{2}{ }^{--}$and exhibits red fluorescence $(\mathrm{Ex} / \mathrm{Em}=510 \mathrm{~nm} / 580 \mathrm{~nm})$. In brief, $1 \times 10^{6}$ cells were incubated with the designated doses of MG132 for $24 \mathrm{~h}$. Cells were then washed in PBS and incubated with $20 \mu \mathrm{M} \mathrm{H}_{2}$ DCFDA, $20 \mu \mathrm{M}$ DHE or $5 \mu \mathrm{M}$ MitoSOX ${ }^{\mathrm{TM}}$ Red at $37^{\circ} \mathrm{C}$ for $30 \mathrm{~min}$ according to the instructions of the manufacturer. DCF, DHE and MitoSOX ${ }^{\mathrm{TM}}$ Red fluorescences were detected using a FACStar flow cytometer (Becton-Dickinson). For each sample, 10,000 events were collected. ROS and $\mathrm{O}_{2}{ }^{--}$levels were expressed as mean fluorescence intensity (MFI), which was calculated by CellQuest software.

Detection of the intracellular glutathione (GSH). Cellular GSH levels were analyzed using 5-chloromethylfluorescein diacetate (CMFDA, Molecular Probes) $(\mathrm{Ex} / \mathrm{Em}=522 \mathrm{~nm} /$ $595 \mathrm{~nm}$ ) as previously described (27). CMFDA is a useful, membrane-permeable dye for determining levels of the intracellular GSH $(28,29)$. In brief, $1 \times 10^{6}$ cells were incubated with the designated doses of MG132 for $24 \mathrm{~h}$. Cells were then washed with PBS and incubated with $5 \mu \mathrm{M}$ CMFDA at $37^{\circ} \mathrm{C}$ for $30 \mathrm{~min}$ according to the instructions of the manufacturer. Cytoplasmic esterases convert non-fluorescent CMFDA to fluorescent 5-chloromethyl-fluorescein, which can then react with GSH. CMF fluorescence intensity was determined using a FACStar flow cytometer (BectonDickinson). For each sample, 10,000 events were collected. Negative CMF staining (GSH depleted) cells were expressed as the percent of (-) CMF cells. CMF levels in live cells without GSH depleted cells were expressed as mean fluorescence intensity (MFI), which was calculated by CellQuest software.
Statistical analysis. The results shown represent the mean of at least two independent experiments; bar and SD. The data were analyzed using Instat software (GraphPad Prism4, San Diego, CA). The student's t-test was used for parametric data. The statistical significance was defined as $\mathrm{p}<0.05$.

\section{Results}

Effects of MG132 on the growth of HeLa cells in vitro. We examined the effect of MG132 on the growth of HeLa cell by trypan blue cell counting. Treatment with 0.5-30 $\mu \mathrm{M}$ MG132 significantly decreased the population of live HeLa cells for $24 \mathrm{~h}$ in a dose-dependent manner (Fig. 1A). In contrast, the number of dead cells dose-dependently increased for $24 \mathrm{~h}$ (Fig. 1A). Collectively, the ratio of dead cells to live cells was increased. When the growth of HeLa cells after treatment with MG132 was also investigated by the MTT assay, dose-dependent reduction of cell growth was observed in HeLa cells with an $\mathrm{IC}_{50}$ of approximately $5 \mu \mathrm{M}$ MG132 for $24 \mathrm{~h}$ (Fig. 1B).

Effects of MG132 on the cell cycle distribution in HeLa cells. We examined the effect of MG132 on the cell cycle distributions in HeLa cells except sub-G1 DNA content cells. As shown in Fig. 2, DNA flow cytometric analysis indicated that treatment with $0.5 \mu \mathrm{M}$ MG132 significantly induced $\mathrm{S}$ and G2-M phase arrests of the cell cycle for $24 \mathrm{~h}$, compared with control cells. Treatment with 1 and $10 \mu \mathrm{M}$ MG132 induced G2-M phase and S phase arrests in HeLa cells, respectively (Fig. 2). Other doses of MG132 (0.1, 5, 20 or $30 \mu \mathrm{M})$ did not induce any specific phase arrests of the cell cycle (Fig. 2).

Effects of MG132 on cell death and mitochondrial membrane potential $(M M P)\left(\Delta \Psi_{m}\right)$ in HeLa cells. Next, we determined whether MG132 induces apoptosis in HeLa cells. As shown in Fig. 3A, treatment with $>0.5 \mu \mathrm{M}$ MG132 slightly increased the number of sub-G1 DNA content cells at $24 \mathrm{~h}$. Treatment with $30 \mu \mathrm{M}$ MG132 significantly elevated the percent of sub-G1 HeLa cells. When we stained HeLa cells with annexin $\mathrm{V}$, the proportion of annexin $\mathrm{V}$-staining cells in 


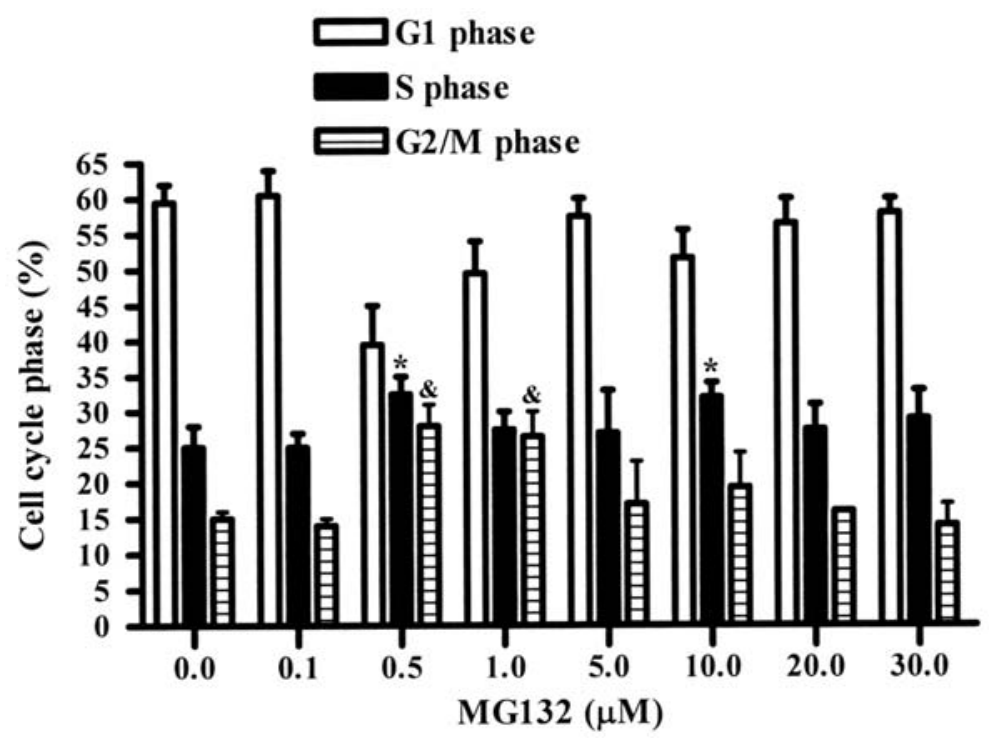

Figure 2. Effects of MG132 on the cell cycle distribution in HeLa cells. Exponentially-growing cells were treated with the indicated concentrations of MG132 for $24 \mathrm{~h}$. The changes of cell cycle distribution were assessed by DNA flow cytometric analysis. ${ }^{*},{ }^{\&} \mathrm{P}<0.05$ compared with the MG132-untreated control cell group. Data are presented as means \pm SD of 3 replicates.

A

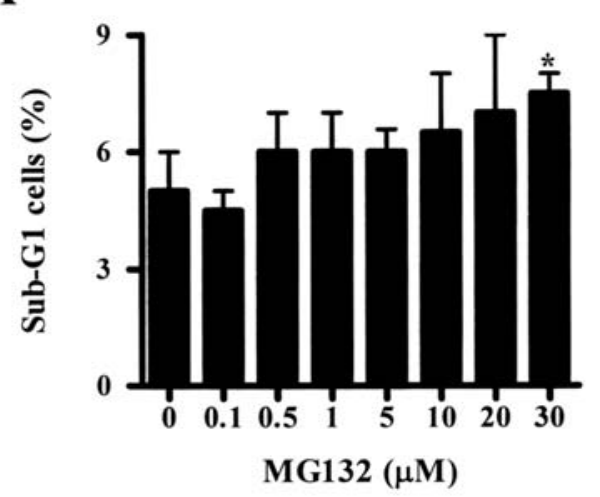

C

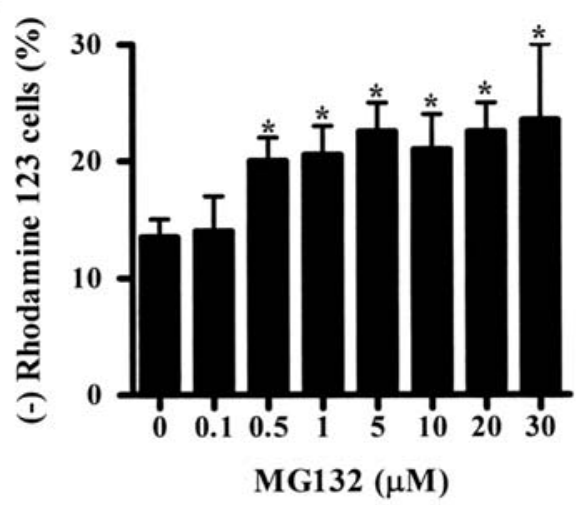

B

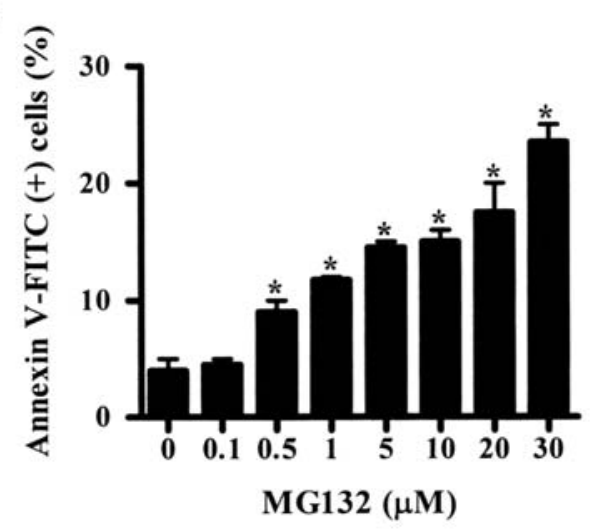

D

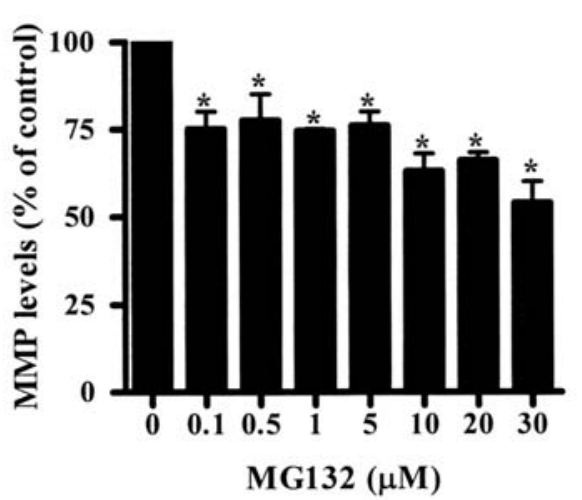

Figure 3. Effects of MG132 on cell death and mitochondrial membrane potential (MMP) $\left(\Delta \Psi_{\mathrm{m}}\right)$ in HeLa cells. Exponentially-growing cells were treated with the indicated concentrations of MG132 for $24 \mathrm{~h}$. (A) The percent of sub-G1 cells in MG132-treated cells. (B) The percent of annexin V positive cells in MG132-treated cells. (C) The percent of Rhodamine 123 negative [MMP $\left(\Delta \Psi_{\mathrm{m}}\right)$ loss] cells in MG132-treated cells. (D) The percent of MMP $\left(\Delta \Psi_{\mathrm{m}}\right)$ levels in HeLa cells except MMP $\left(\Delta \Psi_{\mathrm{m}}\right)$ loss cells. ${ }^{*} \mathrm{P}<0.05$ compared with the MG132-untreated control cell group. Data are presented as means \pm SD of 3 replicates.

$>0.5 \mu \mathrm{M}$ MG132-treated cells was significantly increased in a dose-dependent manner (Fig. 3B). This result indicates that MG132-induced HeLa cell death occurred via apoptosis. To elucidate the effect of MG132 on MMP $\left(\Delta \Psi_{\mathrm{m}}\right)$, MG132treated HeLa cells were stained with Rhodamine 123 dye at $24 \mathrm{~h}$ (Fig. 3C). Treatment with $>0.5 \mu \mathrm{M}$ MG132 induced the 
A

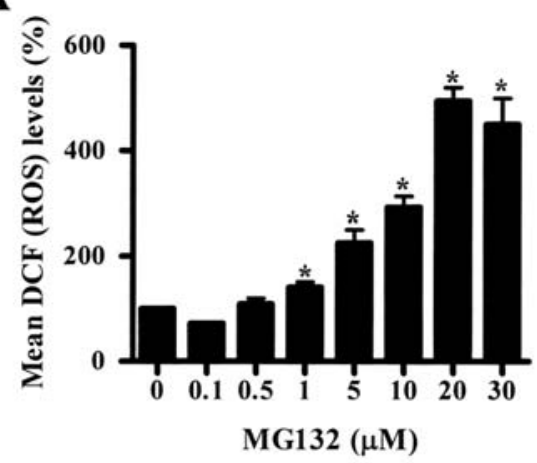

B

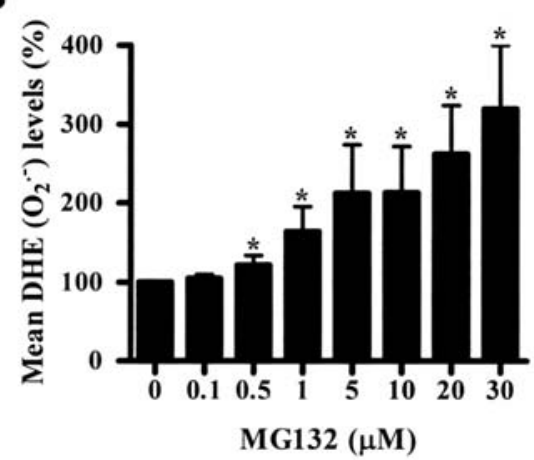

$\mathrm{C}$

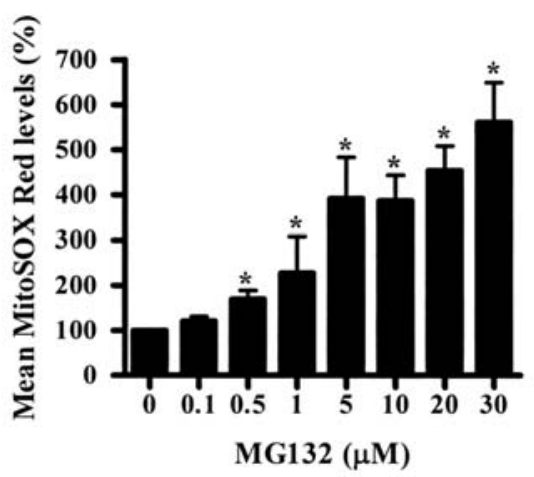

Figure 4. Effects of MG132 on intracellular ROS in HeLa cells. Exponentially-growing cells were treated with the indicated concentrations of MG132 for 24 h. (A) The intracellular DCF (ROS) levels were determined by a FACStar flow cytometer. The graph shows the levels of mean DCF fluorescence (ROS) in MG132-treated cells. (B) The graph shows the levels of mean DHE fluorescence $\left(\mathrm{O}_{2}^{-{ }^{-}}\right)$in MG132-treated cells. (C) The graph shows the levels of mean MitoSOX Red fluorescence (mitochondrial $\left(\mathrm{O}_{2}{ }^{-}\right)$in MG132-treated cells. ${ }^{*} \mathrm{P}<0.05$ compared with the MG132-untreated control cell group. Data are presented as means $\pm \mathrm{SD}$ of 3 replicates.

A

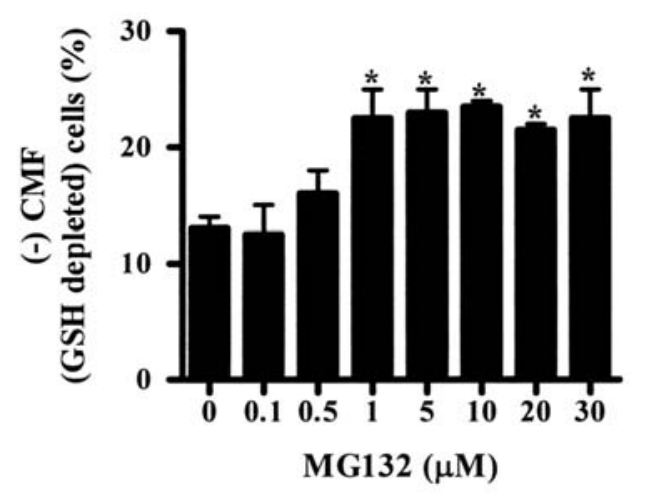

B

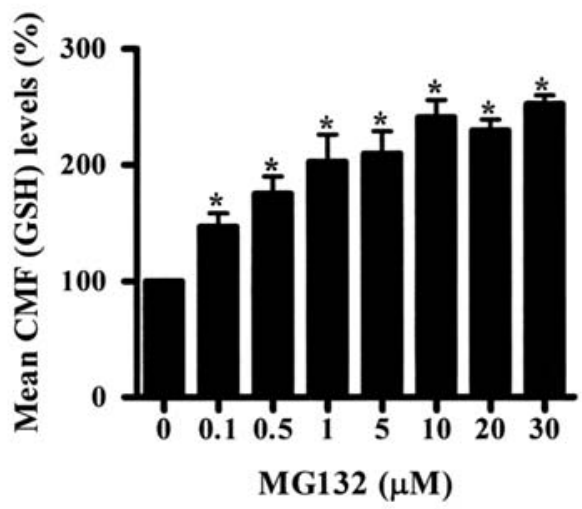

Figure 5. Effects of MG132 on intracellular GSH content in HeLa cells. Exponentially-growing cells were treated with the indicated concentrations of MG132 for $24 \mathrm{~h}$. The intracellular GSH levels were determined by a FACStar flow cytometer as described in Materials and methods. (A) The graph shows the percents of CMF negative (GSH depleted) cells in MG132-treated cells. (B) The levels of mean CMF (GSH content) in MG132-treated cells. ${ }^{*} \mathrm{P}<0.05$ compared with the MG132-untreated control cell group. Data are presented as means \pm SD of 3 replicates.

loss of MMP $\left(\Delta \Psi_{\mathrm{m}}\right)$ in HeLa cells in a dose-dependent manner. In relation to the levels of MMP $\left(\Delta \Psi_{\mathrm{m}}\right)$ in HeLa cells, treatment with MG132 reduced the MMP $\left(\Delta \Psi_{\mathrm{m}}\right)$ level in a dose-dependent manner at $24 \mathrm{~h}$ (Fig. 3D).

Effects of MG132 on intracellular ROS and GSH content in HeLa cells. To assess the changes of the intracellular ROS levels in MG132-treated HeLa cells, we used several fluorescence dyes. As shown in Fig. 4A, the intracellular ROS (DCF) levels were significantly increased in HeLa cells treated with 1-30 $\mu \mathrm{M}$ MG132 for $24 \mathrm{~h}$ (Fig. 4A). In contrast, $0.1 \mu \mathrm{M}$ MG132 reduced the ROS level. Red fluorescence derived from DHE, which reflected $\mathrm{O}_{2}{ }^{--}$accumulation, was significantly increased in HeLa cells treated with 0.5-30 $\mu \mathrm{M}$ MG132 for $24 \mathrm{~h}$ (Fig. 4B). MitoSOX Red fluorescence levels, which specifically indicate $\mathrm{O}_{2}^{-}$levels in the mitochondria, were increased in 0.5-30 $\mu \mathrm{M}$ MG132-treated HeLa cells for $24 \mathrm{~h}$ (Fig. 4C).

Cellular GSH has been shown to be crucial in regulating cell proliferation, cell cycle progression and apoptosis (5). Therefore, we analyzed the changes of GSH levels in HeLa cells using CMF fluorescence. As shown in Fig. 5A, treatment with 0.5-30 $\mu \mathrm{M}$ MG132 depleted the intracellular GSH content in HeLa cells compared with HeLa control cells. When CMF (GSH) levels in HeLa cells except negative CMF staining cells were assessed, the levels of GSH contents were significantly increased in 0.1-30 $\mu \mathrm{M}$ MG132-treated HeLa cells (Fig. 5B).

\section{Discussion}

In the present study, we focused on the effects of MG132 on the growth of human cervix cancer HeLa cells in relation to the cell cycle, apoptosis and changes of ROS and GSH levels. Treatment with MG132 significantly decreased the population of HeLa cells for $24 \mathrm{~h}$ in a dose-dependent manner. The ratio of dead cells to live cells was increased after treatment with MG132 compared with MG132-untreated cells. By an MTT assay, dose-dependent inhibition of cell growth was observed in HeLa cells with an $\mathrm{IC}_{50}$ of approximately $5 \mu \mathrm{M}$ MG132 for $24 \mathrm{~h}$. In addition, MG132 induced apoptosis in HeLa cells in a dose-dependent manner as measured by sub-G1 cells and annexin $\mathrm{V}$ staining cells. 
The cell cycle in eukaryotes is regulated by cyclindependent kinases (CDKs). The cyclins, members of the cell cycle regulators, bind to and activates CDKs. Sequential formation, activation and subsequent inactivation of CDKs and cyclins are critical for control of the cell cycle (30). To explain the mechanism of the cell growth inhibition by MG132 concerning the cell cycle distribution, we did cell cycle analysis in MG132-treated cells. DNA flow cytometric analysis indicated that treatment with $0.5 \mu \mathrm{M}$ MG132 significantly induced both S and G2-M phase arrests of the cell cycle for $24 \mathrm{~h}$. Treatment with 1 and $10 \mu \mathrm{M}$ MG132 induced G2-M phase and S phase arrests in HeLa cells, respectively. Treatment with $0.5,1$ and 10 MG132 resulted in the inhibition of HeLa cell growth approximately 11, 40 and $50 \%$ in the MTT assay, respectively. However, each dose of MG132 induced apoptosis approximately 5, 8 and $11 \%$. Therefore, the $\mathrm{S}$ and/or G2-M phase arrests of the cell cycle can be considered as a pathway to suppress the growth of MG132-treated HeLa cells. Many studies have demonstrated that MG132 induces G2-M phase arrest of the cell cycle in HT-29 colon cancer cells (31) and MG-63 osteosarcoma cells (32) and induced G1 arrest in A549 lung cancer cells (33) and gastric carcinoma cells (34). Although treatment with 5, 20 or $30 \mu \mathrm{M} \mathrm{MG132} \mathrm{had} \mathrm{a} \mathrm{strong} \mathrm{effect} \mathrm{on}$ the inhibition of HeLa cell growth, these doses of MG132 did not significantly induce any specific phase arrest of the cell cycle. Therefore, treatment with 5, 20 or $30 \mu \mathrm{M}$ MG132 presumably induced non-specific arrests at all the phases of the cell cycle. Many cell cycle-related proteins (cyclins A, B, $\mathrm{D}$ and E; p21 and p27) during the cell cycle progression are elaborately degraded by the ubiquitin-proteasomal system (14). Thus, deregulation of the ubiquitin-proteasomal system by MG132 can result in cell cycle arrest in cancer cells. Collectively, these results suggest that the specificity of cell cycle arrest by MG132 depends on differences in incubation doses and cell types.

Proteasome inhibitors including MG132 have been shown to induce apoptotic cell death through formation of ROS (18-22). According to our result, the intracellular ROS levels including $\mathrm{O}_{2}{ }^{-}$were significantly increased in HeLa cells treated with 1-30 $\mu \mathrm{M}$ MG132. It is reported that ROS formation due to proteasome inhibitors may cause mitochondrial dysfunction and subsequent cytochrome c release, which leads to cell viability loss $(20,23)$. The collapse of MMP $\left(\Delta \Psi_{\mathrm{m}}\right)$ occurs during apoptosis (35). Correspondingly, treatment with $>0.5 \mu \mathrm{M}$ MG132 induced the loss of MMP $\left(\Delta \Psi_{\mathrm{m}}\right)$ and reduced MMP $\left(\Delta \Psi_{\mathrm{m}}\right)$ levels in HeLa cells. In addition, mitochondrial $\mathrm{O}_{2}{ }^{--}$levels were increased in the $>0.5 \mu \mathrm{M}$ MG132-treated HeLa cells. Although the mechanism underlying ROS generation after MG132 treatment is not clearly explained, these data suggest that the apoptotic effects of MG132 are tightly related to an increase in intracellular ROS levels including $\mathrm{O}_{2}{ }^{-}$levels and the loss of MMP $\left(\Delta \Psi_{\mathrm{m}}\right)$, and also suggest that the increased ROS levels by MG132 affect the changes of $\operatorname{MMP}\left(\Delta \Psi_{\mathrm{m}}\right)$.

It has been reported that the intracellular GSH content has a decisive effect on anticancer drug-induced apoptosis, indicating that apoptotic effects are inversely comparative to GSH content (36-38). The redox state of cellular GSH is an important modulatory element in the protein ubiquitination pathways (39). It is reported that GSH depletion due to proteasome inhibitors may lead to cell death $(20,23)$. Likewise, our result demonstrated that treatment with $>0.5 \mu \mathrm{M}$ MG132 depleted the intracellular GSH content in HeLa cells compared with HeLa control cells. It is of noteworthy that CMF (GSH) level in HeLa cells, except the negative CMF staining cells, was increased for $24 \mathrm{~h}$. Probably, the increase occurred to reduce ROS increased by MG132. HeLa cells beyond their capacity to resist ROS insult would be dead. These results support the notion that the intracellular GSH levels as well as ROS levels are tightly related to MG132induced cell death.

In conclusion, MG132 inhibited the growth of human cervix cancer HeLa cells via inducing cell cycle arrest as well as triggering apoptosis. The changes of ROS and GSH by MG132 were closely related to apoptosis in HeLa cells. Our results suggest the possibility that the proteasome inhibitor MG132 is a candidate for use in the treatment of cancer.

\section{Acknowledgements}

This study was supported by a grant of the Korea Healthcare Technology R\&D Project, Ministry for Health, Welfare \& Family Affairs, Republic of Korea (A084194).

\section{References}

1. Gonzalez C, Sanz-Alfayate G, Agapito MT, Gomez-Nino A, Rocher A and Obeso A: Significance of ROS in oxygen sensing in cell systems with sensitivity to physiological hypoxia. Respir Physiol Neurobiol 132: 17-41, 2002.

2. Baran CP, Zeigler MM, Tridandapani S and Marsh CB: The role of ROS and RNS in regulating life and death of blood monocytes. Curr Pharm Des 10: 855-866, 2004.

3. Zorov DB, Juhaszova M and Sollott SJ: Mitochondrial ROSinduced ROS release: an update and review. Biochim Biophys Acta 1757: 509-517, 2006

4. Wilcox CS: Reactive oxygen species: roles in blood pressure and kidney function. Curr Hypertens Rep 4: 160-166, 2002.

5. Poot M, Teubert H, Rabinovitch PS and Kavanagh TJ: De novo synthesis of glutathione is required for both entry into and progression through the cell cycle. J Cell Physiol 163: 555-560, 1995.

6. Schnelldorfer T, Gansauge S, Gansauge F, Schlosser S, Beger HG and Nussler AK: Glutathione depletion causes cell growth inhibition and enhanced apoptosis in pancreatic cancer cells. Cancer 89: 1440-1447, 2000.

7. Lauterburg BH: Analgesics and glutathione. Am J Ther 9: 225-233, 2002 .

8. Dasmahapatra G, Rahmani M, Dent P and Grant S: The tyrphostin adaphostin interacts synergistically with proteasome inhibitors to induce apoptosis in human leukemia cells through a reactive oxygen species (ROS)-dependent mechanism. Blood 107: 232-240, 2006.

9. Wallach-Dayan SB, Izbicki G, Cohen PY, Gerstl-Golan R, Fine A and Breuer R: Bleomycin initiates apoptosis of lung epithelial cells by ROS but not by Fas/FasL pathway. Am J Physiol Lung Cell Mol Physiol 290: L790-L796, 2006.

10. Shim HY, Park JH, Paik HD, Nah SY, Kim DS and Han YS: Acacetin-induced apoptosis of human breast cancer MCF-7 cells involves caspase cascade, mitochondria-mediated death signaling and SAPK/JNK1/2-c-Jun activation. Mol Cells 24: 95-104, 2007.

11. Orlowski RZ: The role of the ubiquitin-proteasome pathway in apoptosis. Cell Death Differ 6: 303-313, 1999.

12. Voges D, Zwickl P and Baumeister W: The 26S proteasome: a molecular machine designed for controlled proteolysis. Annu Rev Biochem 68: 1015-1068, 1999.

13. Orlowski M and Wilk S: Catalytic activities of the $20 \mathrm{~S}$ proteasome, a multicatalytic proteinase complex. Arch Biochem Biophys 383: 1-16, 2000. 
14. Adams J: The proteasome: a suitable antineoplastic target. Nat Rev Cancer 4: 349-360, 2004.

15. Drexler HC: Activation of the cell death program by inhibition of proteasome function. Proc Natl Acad Sci USA 94: 855-860, 1997.

16. Shah SA, Potter MW and Callery MP: Ubiquitin proteasome pathway: implications and advances in cancer therapy. Surg Oncol 10: 43-52, 2001.

17. Lee DH and Goldberg AL: Proteasome inhibitors: valuable new tools for cell biologists. Trends Cell Biol 8: 397-403, 1998.

18. Wu HM, Chi KH and Lin WW: Proteasome inhibitors stimulate activator protein-1 pathway via reactive oxygen species production. FEBS Lett 526: 101-105, 2002.

19. Wu HM, Wen HC and Lin WW: Proteasome inhibitors stimulate interleukin-8 expression via Ras and apoptosis signal-regulating kinase-dependent extracellular signal-related kinase and c-Jun N-terminal kinase activation. Am J Respir Cell Mol Biol 27: 234-243, 2002.

20. Ling YH, Liebes L, Zou Y and Perez-Soler R: Reactive oxygen species generation and mitochondrial dysfunction in the apoptotic response to Bortezomib, a novel proteasome inhibitor, in human H460 non-small cell lung cancer cells. J Biol Chem 278: 33714-33723, 2003.

21. Perez-Galan P, Roue G, Villamor N, Montserrat E, Campo E and Colomer D: The proteasome inhibitor bortezomib induces apoptosis in mantle-cell lymphoma through generation of ROS and Noxa activation independent of p53 status. Blood 107: 257-264, 2006.

22. Emanuele S, Calvaruso G, Lauricella M, Giuliano M, Bellavia G, D'Anneo A, Vento R and Tesoriere G: Apoptosis induced in hepatoblastoma HepG2 cells by the proteasome inhibitor MG132 is associated with hydrogen peroxide production, expression of $\mathrm{Bcl}-\mathrm{XS}$ and activation of caspase-3. Int J Oncol 21: 857-865, 2002.

23. Qiu JH, Asai A, Chi S, Saito N, Hamada H and Kirino T: Proteasome inhibitors induce cytochrome c-caspase-3-like protease-mediated apoptosis in cultured cortical neurons. J Neurosci 20: 259-265, 2000.

24. Park WH, Seol JG, Kim ES, Hyun JM, Jung CW, Lee CC Kim BK and Lee YY: Arsenic trioxide-mediated growth inhibition in MC/CAR myeloma cells via cell cycle arrest in association with induction of cyclin-dependent kinase inhibitor, p21, and apoptosis. Cancer Res 60: 3065-3071, 2000.

25. Han YH, Kim SZ, Kim SH and Park WH: Arsenic trioxide inhibits growth of As4.1 juxtaglomerular cells via cell cycle arrest and caspase-independent apoptosis. Am J Physiol Renal Physiol 293: F511-F520, 2007.

26. Setsukinai K, Urano Y, Kakinuma K, Majima HJ and Nagano T: Development of novel fluorescence probes that can reliably detect reactive oxygen species and distinguish specific species. J Biol Chem 278: 3170-3175, 2003.
27. Han YH, Kim SH, Kim SZ and Park WH: Caspase inhibitor decreases apoptosis in pyrogallol-treated lung cancer Calu-6 cells via the prevention of GSH depletion. Int J Oncol 33: 1099-1105, 2008

28. Macho A, Hirsch T, Marzo I, Marchetti P, Dallaporta B, Susin SA, Zamzami N and Kroemer G: Glutathione depletion is an early and calcium elevation is a late event of thymocyte apoptosis. J Immunol 158: 4612-4619, 1997.

29. Hedley DW and Chow S: Evaluation of methods for measuring cellular glutathione content using flow cytometry. Cytometry 15: 349-358, 1994.

30. Kastan MB and Bartek J: Cell-cycle checkpoints and cancer. Nature 432: 316-323, 2004.

31. Wu WK, Wu YC, Yu L, Li ZJ, Sung JJ and Cho CH: Induction of autophagy by proteasome inhibitor is associated with proliferative arrest in colon cancer cells. Biochem Biophys Res Commun 374: 258-263, 2008.

32. Yan XB, Yang DS, Gao X, Feng J, Shi ZL and Ye Z: Caspase-8 dependent osteosarcoma cell apoptosis induced by proteasome inhibitor MG132. Cell Biol Int 31: 1136-1143, 2007.

33. Zhao P, Zhong W, Ying X, Yuan Z, Fu J and Zhou Z: Manganese chloride-induced G0/G1 and $S$ phase arrest in A549 cells. Toxicology 250: 39-46, 2008.

34. Zhang W, Tong Q, Li S, Wang X and Wang Q: MG-132 inhibits telomerase activity, induces apoptosis and G(1) arrest associated with upregulated p27kip 1 expression and downregulated survivin expression in gastric carcinoma cells. Cancer Invest 26: 1032-1036, 2008.

35. Yang J, Liu X, Bhalla K, Kim CN, Ibrado AM, Cai J, Peng TI, Jones DP and Wang X: Prevention of apoptosis by $\mathrm{Bcl}-2$ : release of cytochrome $\mathrm{c}$ from mitochondria blocked. Science 275: 1129-1132, 1997.

36. Estrela JM, Ortega A and Obrador E: Glutathione in cancer biology and therapy. Crit Rev Clin Lab Sci 43: 143-181, 2006.

37. Higuchi Y: Glutathione depletion-induced chromosomal DNA fragmentation associated with apoptosis and necrosis. J Cell Mol Med 8: 455-464, 2004.

38. Park WH, Han YW, Kim SH and Kim SZ: A superoxide anion generator, pyrogallol induces apoptosis in As4.1 cells through the depletion of intracellular GSH content. Mutat Res 619: 81-92, 2007.

39. Jahngen-Hodge J, Obin MS, Gong X, Shang F, Nowell TR Jr, Gong J, Abasi H, Blumberg J and Taylor A: Regulation of ubiquitin-conjugating enzymes by glutathione following oxidative stress. J Biol Chem 272: 28218-28226, 1997. 